\title{
TRALI Syndrome During the Treatment of a Plasmodium falciparum
} Malaria Case Plasmodium falciparum Sitması Tedavisi Esnasında Gelişen TRALI Sendromu Vakası

\author{
Hülya Çaşkurlu, Rahman Nurmuhammedov², Zarni Htway² \\ ${ }^{1}$ Department of Infectious Diseases, Medeniyet University School of Medicine, İstanbul, Turkey \\ 2Department of Internal Medicine, Fatih University School of Medicine, İstanbul, Turkey
}

\begin{abstract}
Malaria, which is one of the three most important infectious diseases globally, is endemic in many areas of the world. Plasmodium falciparum is not endemic to Turkey but can be seen after travel to epidemic countries. Transfusion-related acute lung injury (TRALI) syndrome is a rare disease, which may develop following the transfusion of all types of blood products, including plasma. Here we describe a case of TRALI syndrome in a 29-year-old male, who presented with fever after 15 days of returning from a business trip to Burkina Faso. It developed immediately after the infusion of fresh frozen plasma during the treatment of $P$. falciparum malaria. The patient's condition improved on respiratory support treatment in the intensive care unit for 48 hours without the need of mechanical ventilation. This case indicated that TRALI syndrome has to be considered in the differential diagnosis as an emerging acute lung disease during the treatment of malaria.
\end{abstract}

Keywords: Plasmodium falciparum, TRALI syndrome, transfusion reaction

Received: 27.01.2015 Accepted: 26.07.2016

\section{Öz}

Dünyada en önemli üç enfeksiyon hastalığından biri olan sıtma pek çok bölgede endemik olarak görülür. Plasmodium falciparum Türkiye'de endemik değildir fakat epidemik bölgelere seyahat sonrası görülebilir. Transfüzyonla ilişkili akut Akciğer yaralanması sendromu (TRALi), plazma dahil bütün kan ürünleri transfüzyonundan sonra gelişebilen nadir bir hastalıktır. Burada Burkina Faso ya gittiği iş seyahatinden döndükten 15 gün sonra ateş gösteren TRALi sendromu vakasını tanımladık. Hastanın durumu, mekanik ventilasyona gerek kalmaksızın yoğun bakım ünitesinde solunum destek tedavisiyle 48 saatte iyileşti. Bu vaka sıtma tedavisi sırasında akut akciğer hastalığı geliştiğinde ayırıcı tanıda TRALİ sendromu düşünülmesini göstermektedir.

Anahtar Kelimeler: Prevalence, Cysticercus bovis, Cattle, Iran Geliş Tarihi: 27.01.2015

Kabul Tarihi: 26.07.2016

\section{INTRODUCTION}

Malaria is an infectious disease caused by the members of the genus Plasmodium and is responsible for 2 million annual deaths worldwide (1). According to the latest estimates from the World Health Organization (WHO), there were 214 million new cases of malaria worldwide in 2015 (range 149-303 million). The African region accounted for most global cases of malaria (88\%), followed by the South-East Asia region (10\%) and the Eastern Mediterranean region (2\%) (2). As a result of a highly intense anti-Plasmodium campaign carried out by governmental organizations during the past decade, malaria is now restrict- ed in the southeastern region of Turkey as a sporadic disease caused by P. vivax. However, recently P. falciparum malaria is also diagnosed among the travelers to sub-Saharan Africa. Further, $P$. falciparum malaria can cause severe complications such as deep anemia, cerebral malaria, seizures, hypoglycemia, acute kidney failure, pulmonary edema, lactic acidosis, and death in the absence of prompt and effective treatment $(3,4)$. Therefore, $P$. falciparum malaria needs intense treatment with appropriate anti-malarial drugs as well as with supportive measures such as transfusion of blood and blood products. Post-transfusion complications may interfere with the symptoms and signs of malaria and further complicate the course of the disease.

Address for Correspondence / Yazışma Adresi: Hülya Çaşkurlu E.mail: hcaskurlu@hotmail.com DOI: 10.5152/tpd.2016.4149

CCopyright 2016 Turkish Society for Parasitology - Available online at www.tparazitolderg.org

OTelif hakkı 2016 Türkiye Parazitoloji Derneği - Makale metnine www.tparazitolderg.org web sayfasından ulaşılabilir. 
Transfusion-related acute lung injury (TRALI) is a severe posttransfusion reaction that manifests as acute unset of dyspnea and tachypnea within 6 hours of infusion of blood products. It is currently considered to be a major complication of transfusion. Early recognition of the clinical symptoms may reduce the morbidity and mortality (5). Here we present a case of TRALI syndrome developed during the treatment of $P$. falciparum malaria.

\section{CASE REPORT}

A 29-year-old male resident of Turkey was admitted to a hospital 15 days after returning from a business trip to Burkina Faso with high fever and sweating. He had been admitted to another provincial hospital. The patient was diagnosed with malaria and treated with chloroquine for a total of 6 days. He was later admitted to our hospital due to lack of improvement in his general condition.

His general condition was poor when he was admitted to our hospital. His physical examination revealed $2 \mathrm{~cm}$ of splenomegaly, and his body temperature was $37.6^{\circ} \mathrm{C}$. His other systemic examination findings were normal. Laboratory results were hemoglobin: $12.3 \mathrm{~g} / \mathrm{dL}$, platelets: $164000 / \mathrm{mm}^{3}$, urea: $201 \mathrm{mg} / \mathrm{dL}$, creatinine: $3.4 \mathrm{mg} / \mathrm{dL}, \mathrm{ALT}: 44 \mathrm{U} / \mathrm{L}, \mathrm{AST}: 52 \mathrm{U} / \mathrm{L}, \mathrm{LDH}: 530 \mathrm{U} / \mathrm{L}$, total protein: $6.3 \mathrm{~g} / \mathrm{dL}$, albumin: $2.8 \mathrm{~g} / \mathrm{dL}, \mathrm{CRP}: 161 \mathrm{mg} / \mathrm{l}$, sedimentation: 53/hour, INR: 1.6, total bilirubin: $0.77 \mathrm{mg} / \mathrm{dL}$, and direct bilirubin: $0.65 \mathrm{mg} / \mathrm{dL}$. P. falciparum sporozoites were observed in blood film examination. We started treatment with intramuscular injection of artemether. The patient suddenly developed respiratory failure after being given a unit of fresh frozen plasma because of the prolongation of prothrombin time. Oxygen saturation was $85 \%$ in room air. Chest radiograph revealed bilateral diffuse opacities, and the patient's echocardiography findings were normal (Figure 1). The patient was transferred to the intensive care unit (ICU), and his breathing improved gradually under non-invasive ventilatory support in 48 hours. He was then transferred to the inpatient ward.

Plasmodium became undetectable in blood film preparations on the $4^{\text {th }}$ day of treatment. The patient continued to have high fever. Because his hemoglobin level was $6 \mathrm{~g} / \mathrm{dL}$, after hematology consultation, two units of washed erythrocytes suspension were given. This time, he did not develop lung injury. After the $9^{\text {th }}$ day of admission, the fever started to subside, while his hemoglobin level increased to $8.4 \mathrm{~g} / \mathrm{dL}$. He was discharged on the $18^{\text {th }}$ day. Informed consent has taken from patient for case report.

\section{DISCUSSION}

Malaria is an overwhelming problem in developing countries in tropical regions. It is estimated that up to $40 \%$ of the world's population is at risk of developing malaria. In sub-Saharan Afri$\mathrm{ca}$, most severe cases and deaths occur among children younger than 5 years of age and among pregnant women.

According to the data collected by the Republic of Turkey Ministry of Health, P. vivax is endemic to southeastern Turkey and other types of Plasmodium sporadically surface in other regions, while $P$. falciparum is rare (1). P. falciparum malaria that is related to international travel has been seen in Turkey in recent years (1). Our patient who was a resident of Turkey traveled to Burkina Faso and was admitted to a hospital 15 days after returning.

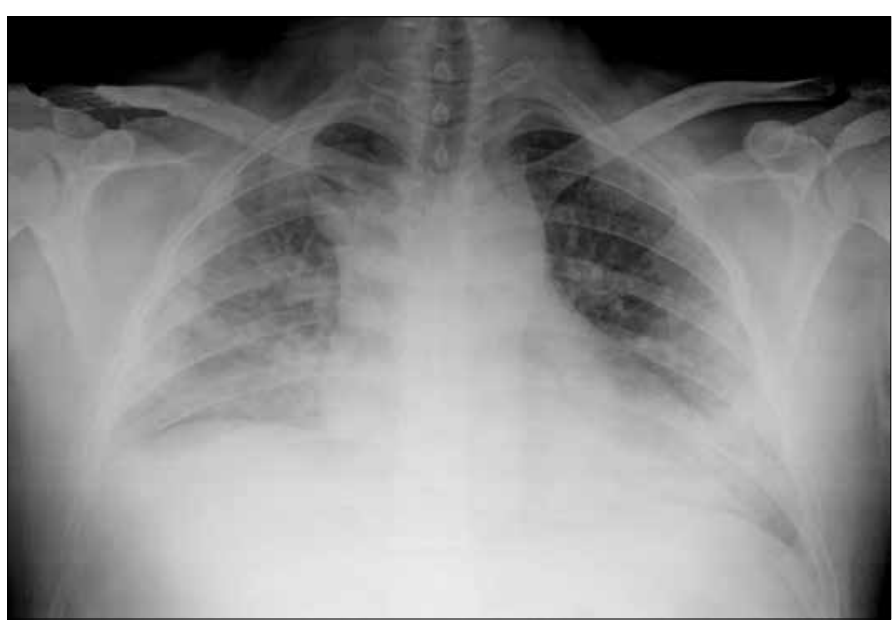

Figure 1. Bilateral infiltrates on chest radiograph following plasma transfusion

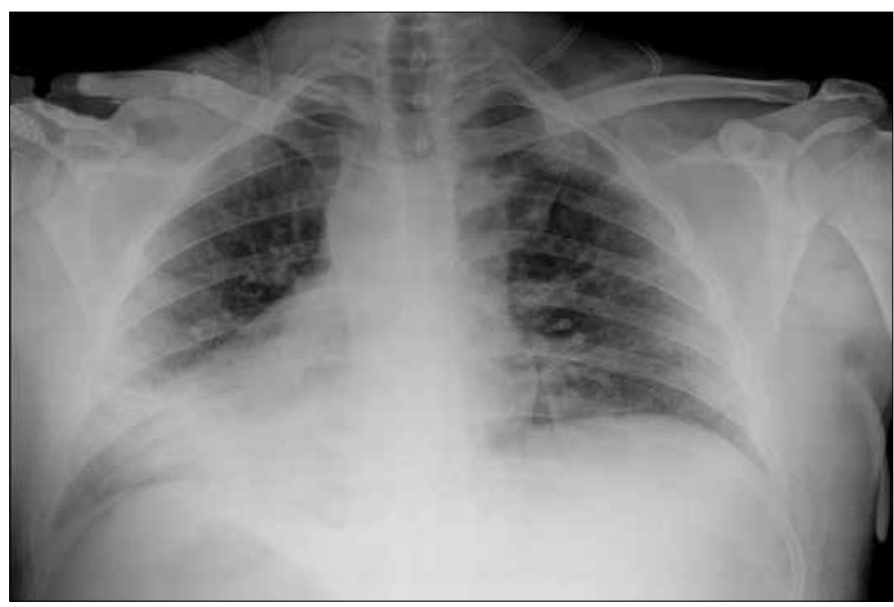

Figure 2. Decline in infiltration in the chest radiograph after 48 hours

P. falciparum malaria can be fatal if not diagnosed and treated promptly. This is especially true in case of non-immune travelers returning from visits to malaria-endemic areas. Severe malaria is associated with the rapid development because anemia-infected, once-infected, and uninfected erythrocytes are hemolytic and removed from the circulation by the spleen (2). Replacement of blood and fluids may lead to rapid reductions in lactate levels, resolution of metabolic acidosis, improvement in renal function, and clinical improvement in critically ill patients (3).

TRALI is a rare but potentially fatal complication of blood product transfusions, which occurs in one in about 5000 transfused blood components. The reported numbers may not reflect the real incidence rates due to unfamiliarity with the syndrome $(6,7)$.

Severe respiratory distress during or within 6 hours of blood transfusion, pulmonary edema, and hypoxemia with normal left ventricular function should be suggestive of TRALI syndrome. TRALI can occur with all blood components, including plasma, platelets, and intravenous immunoglobulin (IVIG) $(8,9)$. Other causes of pulmonary edema should be excluded within TRALI diagnosis, and ARDS, pneumonia, heart failure, volume overload, and acute hemolytic reactions must be considered in differential diagnosis $(12,13)$. The number of diagnosed TRALI cases in Turkey is 
low, potentially because of lack of full diagnosis capabilities and non-infection-related blood transfusions sources of these cases (10-13). Our case was diagnosed with TRALI because respiratory problems were developed soon after plasma transfusion (lower than $90 \%$ oxygen saturation within 6 hours) and bilateral effusion was observed on chest radiograph, echocardiographic findings were normal, and symptoms were healed with 48 hours of support treatment, while all lung indicators were normal before the transfusion of fresh frozen plasma to support the treatment of the serious $P$. falciparum case (Figure 1, 2).

In the diagnosis of TRALI syndrome, awareness of the existence of this syndrome is the most important, followed by early diagnosis $(5,6)$. Mechanical ventilation may be required in the treatment of a severe form of TRALI syndrome, while supplemental oxygen is sufficient in milder forms. Benefits of diuretics and corticosteroids have not been detected. The majority of patients are healed uneventfully within 96 hours. A small group of patients face pulmonary infiltration longer than 7 days, and in $10 \%$ of patients, the disease has been found to result in mortality despite all the supportive treatments (7).

Improvement in our patient's condition was caused by respiratory support in the ICU without the need of mechanical ventilation. Collecting plasma from men only or from women who were never pregnant and limiting unnecessary transfusion are recommended for the prevention of TRALI syndrome (8).

\section{CONCLUSION}

Our goal was to raise awareness by presenting this case because of significantly reduced mortality rates when the diagnosis of TRALI syndrome is considered in those who develop sudden respiratory distress after the transfusion of blood and blood products.

Informed Consent: Informed consent was obtained from patients who participated in this study.

Peer-review: Externally peer-reviewed.

Author Contributions: Concept - H.Ç.; Design - H.Ç.; Supervision - H.Ç.; Funding - H.Ç., R.N.; Materials - H.Ç.; Data Collection and/or Processing - H.Ç., Z.H.; Analysis and/or Interpretation - H.Ç.; Literature Review - H.Ç., Z.H.; Writing - H.Ç.; Critical Review - H.Ç., R.N.

Conflict of Interest: No conflict of interest was declared by the authors.

Financial Disclosure: The authors declared that this study has received no financial support.
Hasta Onamı: Yazılı hasta onamı calışmaya katılan hastadan alınmıştır.

Hakem Değerlendirmesi: Dış bağımsız.

Yazar Katkıları: Fikir - H.Ç.; Tasarım - H.Ç.; Denetleme - H.Ç.; Kaynaklar - H.Ç., R.N.; Malzemeler - H.Ç.; Veri Toplanması ve/veya İşlemesi - H.Ç., Z.H.; Analiz ve/veya Yorum - H.Ç.; Literatür Taraması - H.Ç., Z.H.; Yazıyı Yazan - H.Ç.; Eleştirel İnceleme - H.Ç., R.N.

Çıkar Çatışması: Yazarlar çıkar çatışması bildirmemişlerdir.

Finansal Destek: Yazarlar bu çalışma için finansal destek almadığını belirtmiştir.

\section{REFERENCES}

1. Çaşkurlu H, PakırE, ÇolakA. Evaluation of malaria cases in individuals after traveling to endemic regions of the world. Turk J Med Sci 2014; 44: 168-70. [CrossRef]

2. World Health Organization. World malaria report 2015. Geneva: WHO, 2015.

3. Mandell GL, Bennett JE, Dolin R. Principles andPractice of Infectious Diseases. Sixth Edition. Philadelphia, PA, USA; 2005.p.321-38.

4. Ülçay A, Karaahmetoğlu G, TurhanV, Erdem H, Acar A, Öncül O, et al. The management of therapeutic failure in falciparum malaria patients under oral arthemether-lumefantrinetherapy. Türkiye Parasitol Derg 2014; 38: 61-7. [CrossRef]

5. Kleinman S, Daryl JK. Transfusion-related acute lung injury (TRALI). In: UpToDate, Post TW (Ed), UpToDate, Waltham, MA (Accessed on May 17, 2016).

6. Quest, Graeme R, Gaal H, Clarke G, Nahirniak S. Transfusion-related acute lung injury after transfusion of pooled immune globulin: a case report. Transfusion 2014; 54.12: 3088-91. [CrossRef]

7. Kenz HE, Vander Linden P. Transfusion-related acute lung injury. Eur J Anaesthesiol 2014; 31: 345-50. [CrossRef]

8. Seyhan S. Kan Transfüzyonlarının Nonenfeksiyöz Riskleri.GüncelAnestezi (serial online) 2011 October 26 (cited 2015 January 12). Available from: URL: http://guncelanestezi.com/2011/10/.

9. Teodori J, Rampersad K, Teodori G, RoopchandR, Angelini GD. Transfusion related acute lung injury with massive pulmonary secretion during cardiac surgery. A case report. Journal of Cardiothoracic Surgery 2014; 64. [CrossRef]

10. Basat U, SerinS O, Aksakal B, Yiğit. Gözden Kaçan Bir Tanı; Transfüzyona Bağlı Akut Akciğer Hasarı: Olgu Sunumu. Ş.E.E.A.H. Tıp Bülteni 2014; 48: 248-53.

11. Keskin K, Ulusoy M, Gürkan Y, Ayer A, Kimyon G, Osmanbaşoğlu E, et al. Transfüzyona Bağlı Akut Akciğer Hasarı: Olgu Sunumu. Med Bull Haseki 2006; 44.

12. Baykara N, Demiralp E, Toker E. Blood Transfusion Induced Acute Lung Injury (case report) Turkish Journal of Anesthesiology and Reanimation 2001; 29: 179-82.

13. Beşışık SK, Karahan G, Öztürk G, Tufan F, Oğuz F, Sargın D. Transfüzyona Bağlı Akut Akciğer Hasarı, Nobel Med 2011; 7.2:110-113. 